УДК $34: 4414$

DOI https://doi.org/10.32837/apdp.v0i83.130

Р.С. Пінчук, О. П. Письменна

\title{
ПРАВОВИЙ ЗАХИСТ УЧАСНИКІВ БОЙОВИХ ДІЙ ТА ВЕТЕРАНІВ ВІЙНИ
}

Постановка проблеми. Події на Сході України, які виникли в 2014 році, розширили сферу дії системи соціального захисту. Виникла потреба здійснення соціального захисту військовослужбовців та інших учасників антитерористичної операції (далі - АТО) та операції Об’єднаних сил (далі - ООС), які захищали незалежність, суверенітет та територіальну цілісність України, брали участь у заходах із забезпечення національної безпеки і оборони, відсічі і стримування збройної агресії Російської Федерації у Донецькій та Луганській областях.

Нестабільна політична ситуація зумовлює необхідність підтримання Збройних сил України (далі - ЗСУ), а також Національної гвардії України, Служби безпеки України, Служби зовнішньої розвідки України, Державної прикордонної служби України, Державної спеціальної служби транспорту, Міністерства внутрішніх справ України, Управління державної охорони України, Державної служби спеціального зв'язку та захисту інформації України, Державної служби України з надзвичайних ситуацій, Державної пенітенціарної служби України, інших утворених відповідно до законів України військових формувань у високому боєздатному стані, досягненням якого є ефективна система соціального забезпечення та соціального захисту.

В умовах проведення з 2014 року антитерористичної операції та з 30 квітня 2018 року операції Об’єднаних сил поступово формується і реалізується державна політика щодо обороноздатності України, нормативно закріплюються загальні процедури організації соціального захисту учасників цих подій. Створення ефективної системи соціального захисту учасників бойових (ветеранів війни) потребує розробки та впровадження належного нормативно-правового забезпечення, організаційних, правових, соціально-економічних гарантій.

Аналіз останніх досліджень і публікацій. У період змін у соціально-економічному та політико-правовому житті, проведення АTO (OOC) на Сході нашої країни держава переживає новий досвід державного управління. Проблема створення ефективної системи соціального захисту учасників бойових (ветеранів війни) дій на сьогодні є предметом підвищеної уваги науковців, політиків та громадськості. Водночас, відносна нещодавність виникнення окресленої проблеми зумовлює певну недосконалість нормативно-правового забезпечення з цього питання.

Теоретико-методологічні проблеми соціального захисту та механізмів його реалізації досліджують у своїх роботах В. Скуратівський, В. Вакуленко, Н. Болотіна, Л. Баранник, О. Лаврухінта та інші. Дослідженню нормативно-правових засад соціального захисту учасників бойових дій присвятили роботи такі вчені, як I. Дацюк, О. Кондратенко, М. Кравченко, А. Кириченко, Д. Чижов та інші. Значну роботу в цьому напрямі здійснено колективом громадської організації «Юридична Сотня». Що стосується комплексного дослідження нормативно-правового забезпе-

(C) Р. С. Пінчук, О. П. Письменна, 2019 
чення соціального захисту ветеранів війни, особливо шляхів оптимізації діяльності держави у цій галузі, то таких праць бракує.

Метою статті є дослідження системи нормативно-правового забезпечення соціального захисту учасників бойових дій (ветеранів війни) на сучасному етапі, визначення питань, які потребують подальшого законодавчого регулювання та систематизація нормативно-правових актів за відповідними класифікаційними ознаками.

Виклад основного матеріалу дослідження. Сучасне внутрішнє і зовнішнє становище України визначається сукупністю факторів, що призводять як загроз і ризиків поглиблення кризових явищ, так і можливостей для виходу на магістральний шлях розвитку. В умовах модернізації соціальної політики у сфері безпеки, реформи соціального забезпечення ЗСУ стали найбільш масштабними за весь період незалежності України [1]. Це потребує створення ефективної системи соціального захисту ветеранів війни.

У сучасному законодавстві та науковій літературі немає однозначного визначення терміну «соціальний захист». Зміст цієї категорії науковці розкривають через діяльність, комплекс, функції, систему, сукупність і механізм [2]. Серед учених істотно різняться погляди, коли визначення соціального захисту стосується певних соціальних категорій громадян, яким соціальний захист гарантується у зв'язку зі специфікою їх професійної діяльності $[3,4]$.

У досліджені автори детально зупинилися на соціальному захисті учасників ATO (OOC). Згідно із діючим Законом України «Про статус ветеранів війни, гарантії їх соціального захисту», учасниками бойових дій є особи, які брали участь у виконанні бойових завдань із захисту Батьківщини у складі військових підрозділів, з'єднань, об'єднань всіх видів і родів військ Збройних сил діючої армії (флоту), у партизанських загонах і підпіллі та інших формуваннях як у воєнний, так і у мирний час. До них належать: військовослужбовці Збройних сил України, Національної гвардії України, Служби безпеки України, Служби зовнішньої розвідки України, Державної прикордонної служби України, особи рядового, начальницького складу і військовослужбовці Міністерства внутрішніх справ України, інших утворених відповідно до законів України військових формувань, які захищали незалежність, суверенітет та територіальну цілісність України і брали безпосередню участь в антитерористичній операції, забезпеченні їі проведення, перебуваючи безпосередньо в районах антитерористичної операції у період іï проведення, у здійсненні заходів із забезпечення національної безпеки і оборони, відсічі і стримування збройної агресії Російської Федерації у Донецькій та Луганській областях, забезпеченні їх здійснення, перебуваючи безпосередньо в районах та у період здійснення зазначених заходів [5].

Державна політика у сфері соціального захисту учасників бойових дій полягає у забезпеченні прав, гарантій та компенсацій. Формування системи задоволення певних соціальних потреб ветеранів війни враховує забезпечення їх адаптації та психологічної реабілітації, санаторно-курортним лікуванням, технічними та іншими засобами реабілітації, житлом, надання їм освітніх послуг, дотримання трудових прав, соціальної та професійної адаптації, пільг у сплаті певних видів послуг, пенсійного забезпечення тощо [6]. 
Основу нормативно-правового забезпечення соціального захисту учасників бойових дій становить Конституція України, відповідні закони, Укази Президента України і урядові рішення, програми обласних та місцевих органів самоврядування. Понад стома нормативно-правовими актами регламентуються суспільні взаємовідносини у сфері соціального і правового захисту військовослужбовців та членів їх сімей. Попри це, система соціального захисту учасників бойових дій на сьогодні залишається належно неврегульованою на законодавчому рівні.

Питання соціального захисту учасників бойових дій регламентуються Законом України «Про статус ветеранів війни та гарантій їх соціального захисту» № 45 від 22.10.1993 р. (далі - Закон № 45) [7]. Закон № 45 спрямований на захист учасників бойових дій шляхом встановлення правового статусу учасників бойових дій; забезпечення належних умов для підтримки здоров'я; надання пільг, переваг та соціальних гарантій; формування в суспільстві шанобливого ставлення до них. У законі визначені базові права, пільги та гарантії для учасників бойових дій, але не прописані відповідні механізми та порядки реалізації цих прав, що ускладнює їх використання. На сьогодні система пільг, яка налічує їх понад 20 видів, здебільшого має компенсаторне, а не мотивувальне спрямування, не зважає на особливості сьогодення та не забезпечує гідного рівня життя ветеранів війни.

Процес поліпшення законодавчої бази з питань соціального захисту учасників бойових дій відбувається постійно: переглядаються і доповнюються окремі положення Закону № 45, розширюється перелік осіб, які мають право на статус учасника бойових дій (ветерана війни), учасника ATO (OOC) та Революції Гідності з наданням зазначеним особам відповідних пільг [8]. Протягом 2018 року було внесено п’ять змін та доповнень у Закон України «Про статус ветеранів війни та гарантій їх соціального захисту» та дві зміни в поточному році внесені згідно із Законами № 2684-VIII від 07.02.2019, ВВР, 2019, № 9, ст. 52; №2745-VIII від 06.06.2019, ВВР, 2019, № 30, ст. 119.

Основними законопроектами, підзаконними нормативно-правовими актами та державним програмами, спрямованими на вирішення нагальних питань соціального захисту учасників АTO (OOC), яким надано статус ветерана війни-учасника бойових дій, $є$ :

Указ Президента України «Про додаткові заходи щодо соціального захисту учасників антитерористичної операції» № 150/2015 від 18.03.2015 р. (далі - Указ № 150/2015);

Постанова КМУ «Про затвердження Порядку надання статусу учасника бойових дій особам, які захищали незалежність, суверенітет та територіальну цілісність України і брали безпосередню участь в антитерористичній операції, забезпеченні її проведення» № 413 від 20.08.2014 р. Відповідно до цієї постанови та Указу № 150/2015 у серпні 2014 р. було створено Єдиний державний реєстр учасників бойових дій. Через неузгодженості та прогалини у нормативно-правовій базі, тривалою процедурою їх усунення внесення до реєстру інформації про учасників бойових дій не забезпечено в повному обсязі відповідно до чинного законодавства. Введення до згаданого реєстру обмежено лише відомостями про осіб, які мають 
статус учасника бойових дій, відсутнє наповнення в частині забезпечення житлом, санаторно-курортним лікуванням, психологічною реабілітацією тощо.;

Розпорядження КМУ «Про схвалення Концепції Державної цільової програми з фізичної, медичної, психологічної реабілітації і соціальної та професійної реадаптації учасників АТО на період до 2022 року» № 475-р від 12.07.2017р.;

Постанова КМУ «Про затвердження Порядку організації соціальної та професійної адаптації учасників антитерористичної операції» № 432 від 21.06.2017 p., яка забезпечує утворення дієвого механізму організації відновлення професійних навичок учасників антитерористичної операції як невід’ємної складової їх соціальної адаптації до умов цивільного життя;

Постанова КМУ «Про затвердження Порядку проведення психологічної реабілітації учасників антитерористичної операції» № 497 від 12.07.2017р., яка визначає механізм організації п проведення психологічної реабілітації учасників АТО (ООС) структурними підрозділами з питань соціального захисту. Нормативно-правова неврегульованість спричиняє зменшення обсягів бюджетних призначень, що $€$ неефективним управлінням коштами державного бюджету за напрямами соціального захисту [9].

Недосконалість нормативно-правової бази з питань соціального захисту учасників бойових дій має однією із форм прояву дублювання функцій окремими органами виконавчої влади. Так, згідно з положенням Мінсоцполітики (постанова КМУ № 423 від 17.06.2015р.), одним із основних завдань міністерства є забезпечення формування та реалізації державної політики щодо соціального захисту ветеранів війни та учасників АТО (ООC), зокрема забезпечення їх психологічної реабілітації, санаторно-курортного лікування, соціальної та професійної адаптації учасників АТО (ООС). Постановою КМУ № 986 від 28.11.2018 р. «Питання діяльності Міністерства у справах ветеранів України» ліквідовано Державну службу України у справах ветеранів війни та учасників антитерористичної операції та встановлено, що Міністерство у справах ветеранів України (далі - Мінветеранів) є правонаступником майна, прав та обов'язків цієї служби.

Відповідно Положення про Мінветеранів, затвердженого постановою КМУ № 1175 від 27.12.2018 р., Мінветеранів $є$ головним органом у системі центральних органів виконавчої влади, що забезпечує формування та реалізує державну політику у сфері соціального захисту ветеранів війни, осіб, які мають особливі заслуги перед Батьківщиною, постраждалих учасників Революції Гідності, членів сімей ветеранів та осіб, на яких поширюється чинність Закону України «Про статус ветеранів війни, гарантії їх соціального захисту» [10].

Нині законодавчого врегулювання потребує низка питань, а саме:

- захист прав, грошове забезпечення та визначення механізму компенсаційних виплат родинам у разі загибелі учасника бойових дій;

- страхування життя та здоров'я військовослужбовців;

- затвердження програм медичної та психологічної реабілітації учасників бойових дій [11];

- реформування системи пільгового забезпечення;

- запровадження дієвої системи кредитування житла; 
- затвердження програм соціального забезпечення учасників бойових дій, які були демобілізовані або завершили свій контракт.

Найбільш проблематичним є отримання таких послуг та пільг (третина і більше охочих не змогли ними скористатись):

- забезпечення автомобілем для осіб з інвалідністю внаслідок війни: з 27 опитаних, що зазначили спроби скористатися цією пільгою, лише один респондент отримав автомобіль;

- покращення житлових умов: $62 \%$ охочих не змогли скористатись цією пільгою переважно через відсутність фінансування; також респонденти зазначали, що важко довести підстави для покращення житлових умов. Серед решти тільки кожен десятий з тих, кого було поставлено в чергу, станом на момент опитування зміг покращити житлові умови;

- участь у державних програмах з безоплатної професійної адаптації, курсах 3 підвищення кваліфікації та професійне навчання: 51\% охочих не змогли скористатись цією пільгою в основному через відсутність потрібних курсів або через відмову в участі у курсах на безоплатній основі;

- протезування для осіб з інвалідністю внаслідок війни: $40 \%$ охочих не змогли скористатись цією послугою переважно через незнання, де її можна отримати, або відмову у наданні цієї послуги;

- залишення на роботі при скороченні чи реорганізації підприємства, на працевлаштування в разі ліквідації підприємства, організації: $40 \%$ охочих не змогли скористатись цим правом переважно через примусове звільнення або відсутність документів, необхідних для нового працевлаштування;

- отримання безкоштовних ліків: $39 \%$ охочих не змогли скористатись цією пільгою переважно через те, що в аптеці відмовилися надати препарати безкоштовно, або не було потрібних препаратів, або лікарі відмовлялися виписати відповідний рецепт (мотивуючи це тим, що респонденту все одно не нададуть препарати безкоштовно);

- санаторно-курортне лікування: 39\% охочих не скористалися цією послугою переважно через відмову надати путівку безкоштовно або через відсутність показань для такого лікування. Крім того, деякі респонденти зазначали, що їм пропонували путівку в санаторій, до якого дуже далеко і складно добиратися;

- зубопротезування: 34\% охочих не скористалися цією послугою переважно через відмову в наданні цієї послуги в стоматологічному кабінеті, брак потрібних матеріалів або незнання, де отримати цю послугу.

- першочергове відведення земельної ділянки: $32 \%$ охочих не змогли скористатись цією пільгою переважно через відсутність ділянки в межах адміністративної одиниці, яка підходить респонденту, або відсутність будь-якої вільної ділянки, або відсутність землі з потрібним призначенням та площею відповідно до встановлених норм. Також респонденти зазначали про труднощі з отриманням інформації щодо ділянки у місцевій раді, де ділянка розташована, забюрократизований та довгий процес оформлення, труднощі з реєстрацією ділянки.

Серед причин звернень до Центру соціальних служб сім’і, дітей та молоді (далі - ЦСССДМ), які стосуються складнощів з отриманням тих чи інших послуг 
або пільг, зі значним відривом лідирують проблеми з відведенням земельних ділянок - цю причину звернення зазначили $60 \%$ опитаних працівників ЦСССДМ. 3 них лише 41\% зазначили, що їм переважно вдається допомогти ветеранам вирішити цю проблему.

Окрім проблем матеріального забезпечення, серед ветеранів гостро стоїть проблема безробіття - $19 \%$ опитаних шукають роботу. При цьому охоплення ветеранів послугами центрів зайнятості є високим - 83\% безробітних ветеранів звернулися до центрів зайнятості, 75\% стоять на обліку у центрах зайнятості [12].

На розгляді Верховної Ради України перебуває низка законопроектів, спрямованих на їх вирішення, але швидкість їх розгляду є вкрай низькою.

Для ефективної державної політики щодо соціального захисту ветеранів війни нормативно-правовій базі бракує цілісності, послідовності, систематизації та швидкого реагування на виклики сьогодення.

Систематизуючи нормативні документи за запропонованими класифікаційними ознаками, необхідно зазначити, що один і той же документ може підпадати під різні класи. Сукупність проаналізованих законодавчих актів та норм формують правовий механізм реалізації державної політики щодо соціального захисту учасників бойових дій. За цей час прийнято законопроекти, підзаконні нормативно-правові акти, державні програми, які фрагментарно вдосконалюють систему соціального захисту ветеранів війни.

Для суспільства важливо, щоб захисники держави в умовах воєнної загрози мали підвищений рівень захисту своїх соціальних прав. Подальший розвиток, відповідність сучасним викликам та якість нормативно-правового забезпечення відіграє потужну роль в удосконаленні системи соціального захисту учасників бойових дій.

Висновки. Оцінюючи нормативно-правове забезпечення соціального захисту учасників бойових дій (ветеранів війни), можна зазначити, що на сьогодні у державі сформовано певну організаційно-інституціональну й нормативно-врегульовану систему соціального захисту.

Одним зі здобутків у сфері розбудови соціального захисту є нормативне закріплення загальних процедур організації соціального захисту учасників бойових дій та членів їх сімей щодо: прав і свобод, пільг і соціальних гарантій, спрощення процедур отримання статусу учасника бойових дій, покращення грошового та медичного забезпечення. Незважаючи на досягнення, актуальними залишаються багато законодавчо неврегульованих питань, а саме: захист прав сімей загиблих ветеранів війни, деякі питання щодо надання статусу ветерана війни - учасника бойових дій, реформування системи пільг, створення страхового механізму, запровадження стандартів соціальних послуг та порядків їх надання, адаптація та реабілітація тощо.

На розгляді Верховної Ради України перебуває низка законопроектів, спрямованих на їх вирішення, але швидкість їх розгляду є вкрай незадовільною. На сьогодні державою повинні бути прийняті відповідні закони, які прописують механізми реалізації прав, державних програм та порядків виділення коштів на їх реалізацію. 
Задля поліпшення роботи різних користувачів інформації щодо нормативно-правового забезпечення системи соціального захисту учасників бойових дій розроблено та запропоновано систематизацію нормативно-правових актів за відповідними класифікаційними ознаками: за юридичною силою (законні і підзаконні); за суб'єктами нормотворчості (нормативно-правові акти: Верховної Ради України, міжнародні, Кабінету Міністрів України, Президента України, міністерств та інших центральних органів виконавчої влади); за обсягом і типом дії поширення (загальні, спеціальні та індивідуальні або виняткові).

Подальшої наукової розробки та впровадження належного нормативно-правового регулювання потребують питання щодо грошового, медичного, соціального та інформаційного забезпечення учасників бойових дій. Крім вищезазначених питань, для вдосконалення нормативно-правового забезпечення системи соціального захисту учасників бойових дій доцільним є вивчення міжнародного досвіду із зазначеної проблематики.

\section{Jimepamypa}

1. Про внутрішне та зовнішне становище України у 2017 році: щорічне Послання Президента України до Верховної Ради України. URL: http://www.president.gov.ua/news/poslannya-prezidentaukrayini-do-verhovnoyi-radi-ukrayini-pr-43086.

2. Вакуленко В., Орлатий М. Соціальний захист населення України. Київ : НАДУ, 2010. 212 с.

3. Болотіна Н. Право людини на соціальний захист. Київ: Знання, 2010. 107 с. (Серія «Юридична»).

4. Скуратівський В., Лібанова Е., Палій О. Соціальна політика. Київ : Віпол, 2007. 360 с.

5. Офіційний сайт Міністерства оборони України. Нормативно-правова база. URL: http://www.mil.gov.ua/ministry/normativno-pravova-baza.

6. Кондратенко 0. Загальні засади нормативно-правового забезпечення державного управління у сфері соціального захисту учасників антитерористичної операції та членів їх сімей // Вісник Національної академії державного управління при Президентові України. 2015. № 4. С. 113-120. (Серія «Державне управління»).

7. Офіційний сайт Міністерства у справах ветеранів України. URL: https://mva.gov.ua/ua.

8. Про внесення змін до Закону України «Про статус ветеранів війни, гарантії їх соціального захисту" щодо посилення соціального захисту учасників антитерористичної операції, учасників Революції Гідності та членів сімей загиблих таких осіб № 2203-VIII від 14.11.2017 p. URL: http:// http://zakon3.rada.gov.ua/laws/show/2203-19.

9. Звіт про результати аудиту ефективності використання коштів державного бюджету на заходи із соціальної підтримки учасників антитерористичної операції № 25-1 від 05.12.2017 p. URL: http://http://www.ac-rada.gov.ua/doccatalog/document/16754647/Zvit_25-1_2017.pdf?subportal=main.

10. Постанова КМУ № 1175 від 27.12.2018 р. «Деякі питання Міністерства у справах ветеранів».

11. Кириченко А. Нормативно-правові механізми забезпечення медико-соціального захисту учасників АТО в Україні // Збірник наукових праць співробітників НМАПО ім. П.Л. Шупика. 2016. Вип. 25. С. 435-444. URL: http://nbuv.gov.ua/UJRN/Znpsnmapo_2016_25_69.

12. Біла книга «Аналіз системи державної підтримки ветеранів та їх сімей в Україні». Підготовлена громадською організацією «Юридична сотня» головою Л. Василенко, експертом В. Лавренюк, Ю. Морій. 


\begin{abstract}
Анотація
Пінчук Р. С., Письменна О. П. Правовий захист учасників бойових дій та ветеранів війни. Стаття.

Військовий конфлікт внаслідок збройної агресії Російської Федерації проти України, який розпочався з 27 лютого 2014 р. (захоплення Криму) і триває по сьогоднішній день на Сході України, потребує вирішення багатьох проблем, пов'язаних із соціально-економічним та правовим захистом такої категорії суспільства, як військовослужбовці Збройних Сил України; інші утворені відповідно до законів України військових формувань та правоохоронних органів; осіб, які у складі добровольчих формувань, що були утворені або самоорганізувалися для захисту незалежності, суверенітету та територіальної цілісності України, брали безпосередню участь в антитерористичній операції, забезпеченні iї проведення, перебуваючи безпосередньо в районах антитерористичної операції у період її проведення, за умови, що в подальшому такі добровольчі формування були включені до складу Збройних Сил України, Міністерства внутрішніх справ України, Національної гвардії України та інших утворених відповідно до законів України військових формувань та правоохоронних органів; постраждалих учасників Революції Гідності, членів сімей ветеранів та осіб, на яких поширюється чинність Закону України «Про статус ветеранів війни, гарантії їх соціального захисту».

У статті узагальнено чинні нормативно-правові акти, що регулюють суспільні відносини у сфері соціального захисту учасників бойових дій та ветеранів війни. Визначено основне коло питань, які потребують подальшого законодавчого регулювання соціального захисту учасників ATO (ООС) та іншої категорії осіб, які отримали статус ветерана війни-учасника бойових дій: створення єдиного реєстру учасників АТО (ООС); «єдиного вікна» для отримання соціальних гарантій, передбачених законодавством України, що дозволить забезпечити їм та їхнім сім'ям належний рівень соціального захисту; створення дієвого механізму забезпечення житлом; підвищення ефективності існуючої системи пільг та компенсацій для учасників бойових дій і членів їхніх сімей; створення системи психологічної та фізіологічної реабілітації; забезпечення санаторно-курортним лікуванням; медичним обслуговуванням та протезуванням.
\end{abstract}

Через брак коштів та недосконалість інфраструктури для забезпечення задекларованих соціальних гарантій у ветеранів війни панує думка, що держава робить недостатньо для своїх ветеранів.

Готовність держави регулярно змінювати політику, бюджетні програми та норми законів - це все те, що характеризує сучасні успішні моделі підтримки учасників бойових дій та ветеранів війни. У кожній із цих моделей активну роль відіграє суспільство і органи місцевого самоврядування.

Система державної підтримки ветеранів в Україні потребує негайного перегляду і переформатування. Поглиблене розуміння специфіки проблем функціонування недосконалої системи державної підтримки ветеранів війни дає можливість переосмислити потреби, а відповідно, і переглянути форми підтримки ветеранів війни - учасників бойових дій.

Ключові слова: учасник антитерористичної операції, учасник операції Об'єднаних сил, учасник бойових дій, ветеран війни, соціальний захист, нормативно-правовий акт, система нормативно-правового забезпечення, суб'єкти нормотворчості.

\title{
Summary
}

Pinchuk R.S., Pysmenna O.P. Legal protection of combatants and war veterans. - Article.

The military conflict resulting from the armed aggression of the Russian Federation against Ukraine, which began on February 27, 2014 (the seizure of Crimea) and continues to the present day in the East of Ukraine, requires solving many problems related to the socio-economic and legal protection of such a category of society as : servicemen of the Armed Forces of Ukraine; other military units and law enforcement agencies formed in accordance with the laws of Ukraine; persons who, as a part of voluntary formations formed or self-organized to protect the independence, sovereignty and territorial integrity of Ukraine, directly participated in the anti-terrorist operation, ensuring its conduct, staying directly in the areas of the anti-terrorist operation during its period, during Subsequently, such volunteer units were included in the Armed Forces of Ukraine, the Ministry of Internal Affairs of Ukraine, the National Guard of Ukraine and other entities established in accordance with the law. Ukraine in military units and law enforcement agencies; the victims of the Dignity Revolution, members of veterans' families, and persons covered by the Law of Ukraine "On the Status of War Veterans, Guarantees of their Social Protection".

This article summarizes the current regulations governing social relations in the field of social protection for combatants and war veterans. The main issues that require further legislative regulation of the social protection of participants of the ATO $(\mathrm{OOS})$ and other category of persons who have received the status of war veteran-participant of the war are defined: creation of a unified register of participants ATO; a "one-stop shop" for obtaining the social guarantees provided by the legislation of Ukraine, which will allow to provide them and their families with an adequate level of social protection; creation of an effective mechanism for providing housing; increasing the effectiveness of the existing benefits and compensation 
system for combatants and their families; creation of a system of psychological and physiological rehabilitation; provision of spa treatment; health care and prosthetics.

Due to the lack of funds and the lack of infrastructure to provide declared social guarantees for war veterans, it is believed that the state is doing little for its veterans.

The readiness of the state to change policies, budget programs and rules of law on a regular basis is all that characterizes modern successful models of support for participants of war and war veterans. In each of these models, society and local governments play an active role.

The state support system for veterans in Ukraine needs immediate revision and reformatting. An indepth understanding of the specifics of the functioning of the imperfect system of state support for war veterans makes it possible to rethink the needs and, accordingly, to review the forms of support for war veterans - participants in hostilities.

Key words: participant of anti-terrorist operation, participant of Operation United forces, participant of combat operations, veteran of war, social protection, normative legal act, system of regulatory legal support, subjects of rulemaking. 